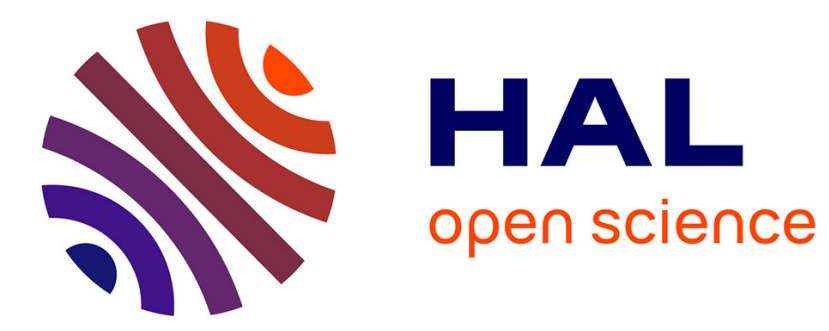

\title{
Low Loss of Fine Grained Mn-Zn Ferrite
}

\author{
Y. Yamamoto, A. Makino, T. Nikaidou
}

\section{To cite this version:}

Y. Yamamoto, A. Makino, T. Nikaidou. Low Loss of Fine Grained Mn-Zn Ferrite. Journal de Physique IV Proceedings, 1997, 07 (C1), pp.C1-123-C1-124. 10.1051/jp4:1997139 . jpa-00255086

\section{HAL Id: jpa-00255086 https://hal.science/jpa-00255086}

Submitted on 1 Jan 1997

HAL is a multi-disciplinary open access archive for the deposit and dissemination of scientific research documents, whether they are published or not. The documents may come from teaching and research institutions in France or abroad, or from public or private research centers.
L'archive ouverte pluridisciplinaire HAL, est destinée au dépôt et à la diffusion de documents scientifiques de niveau recherche, publiés ou non, émanant des établissements d'enseignement et de recherche français ou étrangers, des laboratoires publics ou privés. 


\title{
Low Loss of Fine Grained Mn-Zn Ferrite
}

\author{
Y. Yamamoto, A. Makino and T. Nikaidou
}

Central Research, Alps Electric Co., Ltd., 1-3-5 Higashitakami, Nagaoka 940, Japan

\begin{abstract}
Mn-Zn ferrite with grain size of $1.5 \mu \mathrm{m}$ was obtained by sintering hydrothermal-precipitated powders with uniform dispersion of additions. The fine grain size and high density were realized simultaneously by the use of fine particle ferrite powder and fine particle additives, planetary ball mill mixing of MnZn ferrite powder and additives and low temperature sintering. The core loss of a newly developed ferrite with fine grain was significantly reduced to that of a commercial ferrite.
\end{abstract}

\section{Introduction}

Recently, power supplies are required to reduce the volume and the thickness in compliance with miniaturization in the portable electronic equipments and the on-board power supply modules. As an increase in the driving frequency is an effective method for these purpose, core materials with low core losses at high frequency are earnestly desired. Mn- $\mathrm{Zn}$ ferrites generally have lower core losses at high frequency in comparison with $\mathrm{Ni}-\mathrm{Zn}$ ferrites and metallic magnetic materials. We have reported [1,2] that the finning the grain size of the $\mathrm{Mn}-\mathrm{Zn}$ ferrite is effective for the reduction of core losses at the frequency range from 1 to $2 \mathrm{MHz}$, mainly due to the reduction of the residual loss which is a dominant part of the core losses at the high frequency. In this study, we tried to realize simultaneously the fine grain size and uniform dispersion of additions such as $\mathrm{SiO} 2, \mathrm{CaCO}, \mathrm{Ta2} \mathrm{O}$, $\mathrm{TiO} 2$ by (1) using hydro-thermal precipitated $\mathrm{Mn}-\mathrm{Zn}$ ferrite powder with $0.13 \mathrm{~mm}$ in size and the additions with small particle sizes, and (2) mixing the powders in a planetary ball mill.

\section{Experimental procedure}

The $\mathrm{MnZn}$ ferrite powder for the sintered bodies were prepared by the hydrothermal method. A hydrothermal-precipitated ferrite powder (particle size : $0.13 \mu \mathrm{m}$ ) with composition of $\mathrm{Mn} 0.72 \mathrm{Zn} 0.16 \mathrm{Fe} 2.1204$ was used at a starting material. The additions were added to the ferrite powder, mixed by planetary ball mill and this uniform mixture of the ferrite powder and the additions were calcined in a reduced atmosphere. Sample $A$ and $C$ were undoped and sample B and D were doped with $0.01 \mathrm{wt} \%$ of SiO2 (particle size : $0.012 \mu \mathrm{m}$ ), $0.021 \mathrm{wt} \%$ of $\mathrm{CaCO}$ (particle size : $0.04 \mu \mathrm{m}$ ), $0.038 \mathrm{wt} \%$ of Ta2O5 (particle size : $0.3 \mu \mathrm{m}$ ) and $0.034 \mathrm{wt} \%$ of TiO2 (particle size : $0.5 \mu \mathrm{m}$ ). Sample $A$ and B were calcined at $973 \mathrm{~K}$ and sample $\mathrm{C}$ and D were calcined at 1173K. The calcined powders were milled by planetary ball mill, dried, mixed with a proper quantity of organic binder, pelletized, cold isostatically pressed at $275 \mathrm{MPa}$ for $180 \mathrm{~s}$ and sintered at $1323 \mathrm{~K}$ for $14.4 \mathrm{ks}$ in a reduced atmosphere. The microstructure was observed with a optical microscope. The electric resistivity $(\rho)$ was measured by the four-point probe method. The permeability $\left(\mu^{\prime}, \mu^{\prime \prime}\right)$ and tan $\partial$ were measured under a field of $0.4 \mathrm{~A} / \mathrm{m}$ with a impedance analyzer. The core loss (Pc) was measured with an $\mathrm{B}-\mathrm{H}$ analyzer. The hysteresis loss $(\mathrm{Ph})$ was determined by extrapolating the $(\mathrm{Pc} / \mathrm{f})-\mathrm{f}$ plots to $\mathrm{f}=0$. The classical eddy current loss $(\mathrm{Pe})$ is given as equation (1) under a model of simultaneous rotation magnetization process [3].

$\mathrm{Pe}=\left(\pi^{2} \mathrm{f}^{2} \mathrm{Bm} \mathrm{m}^{2} \mathrm{~d}^{2}\right) / 6 \rho \quad\left(\mathrm{W} / \mathrm{m}^{3}\right) \cdots \cdots(1)$ where $d$ is thickness and $\rho$ is electrical resistivity. Residual loss (Pr) is calculated as $\mathrm{Pr}=\mathrm{Pc}-\mathrm{Ph}-\mathrm{Pe}$. The samples were ring-shaped, with outer and inner diameter of 8 and $4 \mathrm{~mm}$, respectively, and a thickness of $2.0 \mathrm{~mm}$. The mag-

Table 1. Densities, grain sizes, electric resistivities and core losses of sample A, B, C and Dprepared by sintering at $1323 \mathrm{~K}$

\begin{tabular}{lcccccc}
\hline & Additions & $\begin{array}{c}\text { Calcining } \\
\text { temperature } \\
(\mathrm{K})\end{array}$ & $\begin{array}{c}\text { Relative } \\
\text { density } \\
(\%)\end{array}$ & $\begin{array}{c}\text { Grain } \\
\text { size } \\
(\mu \mathrm{m})\end{array}$ & $\begin{array}{c}\text { Electric } \\
\text { resistivity } \\
(\Omega \cdot \mathrm{cm})\end{array}$ & $\begin{array}{c}\text { Core loss } \\
(\text { at } 1 \mathrm{MHz}, 50 \mathrm{mT}) \\
\left(\mathrm{kW} / \mathrm{m}^{3}\right)\end{array}$ \\
\hline Sample A & No & 973 & 97.2 & 3.4 & 7.5 & 730 \\
Sample B & Yes & 973 & 98.8 & 1.5 & 63 & 450 \\
Sample C & No & 1173 & 97.2 & 1.8 & 2.8 & 720 \\
Sample D & Yes $^{* 1}$ & 1173 & 98.6 & 1.5 & 135 & 270 \\
\hline
\end{tabular}

* $1: \mathrm{SiO} 2=0.01 \mathrm{wt} \%, \mathrm{CaCO}=0.012 \mathrm{wt} \%, \mathrm{Ta2O}=0.038 \mathrm{wt} \%, \mathrm{TiO} 2=0.034 \mathrm{wt} \%$ 
netic properties of the commercial power ferrite were compared with a newly developed ferrite.

\section{Results and discussion}

Table 1 shows the densities, the average grain sizes, the electric resistivities and magnetic properties of the sample A,B,C and D. The increases of the $\rho$ and the decreases of the core losses by adding $\mathrm{Si}, \mathrm{Ca}$, Ta and Ti. Figure 1 shows the frequency dependence of $\mu^{\prime}, \mu^{\prime \prime}$ and the relative loss factor $\left(\tan \partial / \mu^{\prime}\right)$ of the doped sample $\mathrm{D}$, which shows the minimum $\mathrm{Pc}$, and the commercial ferrite. A noteworthy finding is that the relative loss factor in the lower frequency range of the two are in agree but in the higher frequency range that of the sample $D$ remarkably decrease, namely, the effectiveness of the sample $D$ for the high frequency transformer is confirmed.

To consider the reason of the superior core loss property of the sample $D$, the relationship of the core loss per cycle and the frequency of the two samples are plotted (Fig. 2). A mutual relationship of the two is strikingly similar to the mutual relationship of frequency dependence of the relative loss factor (Fig.1). In the lower frequency resion the core losses per cycle are irrelevant to the frequency and the core loss of this frequency region are caused by hysteresis loss. An important matter is that the core loss per cycle in the lower frequency region of the two are approximately equal and the effect of the large difference of the average grain sizes of the two ( sample D:1.5 $\mu \mathrm{m}$, commercial ferrite:9.5 $\mu \mathrm{m}$ ) is not actualized. Accordingly, this suggest that the core loss per cycle in the lower frequency region can be eliminated the effect of the grain sizes of the samples. On the other hand, in the higher frequency region the frequency dependence of the core loss per cycle are noticed, the frequency dependence of the Pc for the sample $D$ occurs in higher frequency than the commercial ferrite.This frequency region corresponds to the region of the eddy current loss or the residual loss. Therefore, the additional effect of Si, $\mathrm{Ca}, \mathrm{Ta}$ and $\mathrm{Ti}$ is concluded as the suppressive effect of these losses in high frequency.

Table 2 shows the physical properties and core losses of the sample D and commercial ferrite. It is noticeable that the core loss in high frequency of the commercial ferrite is higher than that of the sample $D$, in spite of considerably higher electric resistivity than sample D.Therefore, if the core loss depend on the eddy current loss, the eddy current loss cannot be explained by the de-resistivity originated in a grain boundary barrier. For this reason, the eddy current loss which is attributable to the bulk conductivity seems to be the most probable. In this case, it is supposed two capabilities as arusult of the dissolution of the dopant to the bulk, one is the inhibition of the hopping between $\mathrm{Fe}^{3+}$ and $\mathrm{Fe}^{2+}$ for the bulk and another is the inhibition of the resultant electrons by the thermal dissociation of the constituent oxygen of the ferrite, these two possibilities are under investigation. This estimation as described above is in harmony with the fact that the core loss of the dope than that of the doped sample calcined at $973 \mathrm{~K}$ (Table 1); It can be considered that the high temperature calcined sample bas a highly inhibitory action, the above mentioned, as the increase of amount of dopants dissolution into the bulk. Furthermore, the increase of the dc-resistivity and the decrease of the core loss for doped samples of Table 1 are comprehended by considering the simultaneous occurring of the deposition / segregation of the dopant to the grain boundary and the dissolution to the bulk. On the other hand, if the core loss in the high frequency region originates in the residual loss, a model can be considered that cation vacancies and anion vacancies are created by doping and then the magnetic wall displacement or the rotation of the magnetization is pinned by these vacancies.

Table 2. Comparison of physical properties and separated core losses of the sample D and commercial ferrite.

\begin{tabular}{|c|c|c|c|c|c|c|c|}
\hline & \multirow{2}{*}{$\begin{array}{c}\text { Grain size } \\
(\mu \mathrm{m})\end{array}$} & \multirow{2}{*}{$\begin{array}{l}\text { Resistivity } \\
(\Omega \cdot \mathrm{cm})\end{array}$} & \multirow{2}{*}{ Permeability } & \multicolumn{3}{|c|}{ Core loss (1MHz, $\left.25 \mathrm{mT}, 40^{\circ} \mathrm{C}\right)$} & \multirow{2}{*}{$\begin{array}{c}\mathrm{kWm}^{-3} \\
\text { Residual } \\
\text { loss }\end{array}$} \\
\hline & & & & $\begin{array}{l}\text { Total } \\
\text { loss }\end{array}$ & $\begin{array}{c}\text { Hysteresis } \\
\text { loss }\end{array}$ & $\begin{array}{c}\text { Eddy current } \\
\text { loss }\end{array}$ & \\
\hline Sample D & 1.5 & 135 & 1600 & 25 & 10 & 7 & 8 \\
\hline $\begin{array}{c}\text { Commercjal } \\
\text { ferrite }\end{array}$ & 9.5 & 960 & 2900 & 208 & 15 & 79 & 114 \\
\hline
\end{tabular}

References

[1] Y.Yamamoto and A.Makino:Journal of Magnetism and Magnetic Materials 133(1994)500.
[2] A.Makino and Y.Yamamoto:in New horizons for Materials, ed.P. Vincenzini, Thchna, (1995)361.

[3] J.Smit and H.P.J.Wijn : "Ferrites", Philips Technical library, Eindhoven, (1959)134. 